\title{
Induced Systemic Resistance Against Citrus Canker Disease by Rhizobacteria
}

\author{
Nadia Riera, Han Wang, Yong Li, Jinyun Li, Kirsten Pelz-Stelinski, and Nian Wang ${ }^{\dagger}$
}

First, second, third, and fourth authors: Citrus Research and Education Center, Department of Microbiology and Cell Science, University of Florida/Institute of Food and Agricultural Sciences, Lake Alfred; fifth author: Citrus Research and Education Center, Department of Entomology and Nematology, University of Florida/Institute of Food and Agricultural Sciences, Lake Alfred; and sixth author: China-USA Citrus Huanglongbing Joint Laboratory (A joint laboratory of The University of Florida's Institute of Food and Agricultural Sciences and Gannan Normal University), National Navel Orange Engineering Research Center, Gannan Normal University, Ganzhou, Jiangxi, China; Citrus Research and Education Center, Department of Microbiology and Cell Science, University of Florida/Institute of Food and Agricultural Sciences, Lake Alfred.

Accepted for publication 2 April 2018.

\begin{abstract}
Citrus canker, caused by Xanthomonas citri subsp. citri, is an important citrus disease that causes significant economic losses worldwide. All commercial citrus varieties are susceptible to citrus canker. Currently, chemical control with copper based products is the main approach to control $X$. citri subsp. citri dispersal and plant colonization. However, extensive use of copper compounds can result in copper-resistant strains and cause adverse effects on the environment. Alternatives to chemical control involve the activation of citrus immunity to control the disease. Here, we investigated the ability of multiple rhizobacteria to induce a systemic defense response in cultivar Duncan grapefruit. Burkholderia territorii strain A63, Burkholderia metallica strain A53, and Pseudomonas geniculata strain 95 were found to effectively activate plant defense and significantly reduce symptom development in leaves challenged with $X$. citri subsp. citri. In the priming phase, root application of $P$. geniculata induced the expression of salicylic

acid (SA)-signaling pathway marker genes (PR1, PR2, PR5, and salicylic acid carboxyl methyltransferase [SAM-SACM]). Gene expression analyses after $X$. citri subsp. citri challenge showed that root inoculation with P. geniculata strain 95 increased the relative levels of phenylalanine ammonia lyase 1 and SAM-SACM, two genes involved in the phenylpropanoid pathway as well as the biosynthesis of SA and methyl salicylate (MeSA), respectively. However, hormone analyses by UPLC-MS/MS showed no significant difference between SA in $P$. geniculata-treated plants and control plants at 8 days post-beneficial bacteria root inoculation. Moreover, $P$. geniculata root-treated plants contained higher reactive oxygen species levels in aerial tissues than control plants 8 days post-treatment application. This study demonstrates that rhizobacteria can modulate citrus immunity resulting in a systemic defense response against $X$. citri subsp. citri under greenhouse conditions.
\end{abstract}

Citrus canker is a globally distributed disease that affects all commercial citrus varieties. The causal agent, Xanthomonas citri subsp. citri, infects plants through stomata or wounds, multiplies in the intercellular spaces, and causes characteristic necrosis and raised lesions in fruit, leaves, and twigs (Ryan et al. 2011). Chemical control based on copper compounds is currently the most frequent treatment for this disease. However, use of copper compounds may cause phytotoxicity in the fruit peel (Graham et al. 2008) and have a negative impact on the environment (Alva et al. 1995). Specifically, prolonged use of copper may lead to copper accumulation in the soils (Zhang et al. 2003b). Copper at concentrations of $>100 \mathrm{mg} / \mathrm{kg}$ can cause phytotoxicity with subsequent decreased citrus productivity (Alva 1993). In addition, copper accumulation has been reported to reduce microbial biomass and diversity in the copper affected soils (Zhou et al. 2011). Aquatic organisms are more susceptible to copper contamination than terrestrial plants (Eisler 1998), and the transport of copper from land to surface waters has been identified as an environmental issue (Zhang et al. 2003a). Copper-based compounds

†Corresponding author: N. Wang; E-mail: nianwang@ufl.edu

Author contributions: N.W. and N.R. design and developed the experimental design. N.R. performed the experiments. H.W. and N.R. performed the hormone extraction and analysis. Y.L. and J.L. performed the gene expression analyses. N.R., J.L., and N.W. wrote the manuscript. All authors read and approved the final manuscript.

Funding: This study has been supported by Florida Citrus Initiative Program and Citrus Research and Development Foundation.

(c) 2018 The American Phytopathological Society have no systemic activity in the plant and the control effect relies on their multiple applications throughout the year and their protective effect decreases with heavy winds and rains (Graham and Myers 2016; Stall et al. 1980). Moreover, copper resistant $X$. citri subsp. citri strains have been identified in Argentina and more recently in Reunion Island (Behlau et al. 2012; Richard et al. 2016). The adverse side effect of copper-based chemical applications calls for development of other canker control strategies.

A possible alternative for chemical control is the activation of the plant immune system systemically, called "priming" (Balmer et al. 2015). Systemic resistance occurs naturally in plants upon proper stimulation by certain pathogens, nonpathogens, herbivory and/or some chemical treatments (Kuć 1982). After the stimulus is recognized, the plant immune system is systemically activated in distal aerial tissues to better protect them from future pathogen attack. In citrus, most studies on priming against biotic stresses have focused their attentions on the chemical elicitors (Francis et al. 2009; Graham and Myers 2013; Hu et al. 2018; Li et al. 2016, 2017). For instance, acibenzolar-S-methyl (ASM), isonicotinic acid (INA), and DL-3-aminobutyric acid (BABA) have been evaluated for their protective effect against citrus canker, Diaphorina citri development, and Huanglongbing disease (Francis et al. 2009; Graham and Myers 2013; Li et al. 2016; Tiwari et al. 2013). Application of ASM as well as INA as a soil drench resulted in reduced disease development in small plants inoculated with $X$. citri subsp. citri under greenhouse conditions (Francis et al. 2009).

The activation of systemic resistance in plants can also be triggered by plant growth promoting rhizobacteria (PGPR) or bacteria (PGPB) (van Loon et al. 1998). Different PGPR strains 
have been reported to induce plant defense against a broad spectrum of pests including oomycetes, fungi, bacteria, insects, and nematodes (Walters and Bennett 2014). Microbial-mediated priming has been linked with differential expression of defense related genes, changes in phytohormone content, changes in reactive oxygen species (ROS) levels, sugars as well as amino acids and tricarboxylic acid (TCA) components (Balmer et al. 2015). PGPR induction of defense has been mostly associated with the jasmonate/ethylene (JA/ET) pathways of plant defense (Zamioudis and Pieterse 2012). Additionally, SA-dependent PGPR induction of resistance has been reported (Barriuso et al. 2008; Niu et al. 2016; van de Mortel et al. 2012). Use of PGPR in the field has been suggested as an alternative strategy for sustainable disease control. Different PGPR promoting a protective effect in plants have been used in field conditions as part of crop protection strategies against chili wilt disease and blast disease in rice (Lucas et al. 2009; Raguchander et al. 2012).

In this work, we investigated the effect of application of multiple PGPR in inducing plant defense against citrus canker. Three rhizobacteria, Burkholderia territorii strain A63, Burkholderia metallica strain A53, and Pseudomonas geniculata strain 95, were found to evoke a plant defense response against citrus canker. For $P$. geniculata strain 95, we also investigated the putative modes of action associated with the induction of defense responses against citrus canker.

\section{MATERIALS AND METHODS}

Bacterial cultures and growth conditions. Bacterial isolates were cultured in nutrient broth (NB) or on nutrient agar (NA) at $28^{\circ} \mathrm{C}$ for $24 \mathrm{~h}$. For plant inoculation, bacterial strains were grown overnight in $\mathrm{NB}$ at $28^{\circ} \mathrm{C}$ with agitation at $200 \mathrm{rpm}$. Cells were centrifuged at $10,000 \times g$ for $20 \mathrm{~min}$ and then suspended in sterile distilled water to a final concentration of $10^{8} \mathrm{CFU} / \mathrm{ml}$. X. citri subsp. citri strain 306 (Rybak et al. 2009) was grown in NB or on NA medium at $28^{\circ} \mathrm{C}$. Seven bacterial strains were selected to screen for their ability to induce systemic resistance in cultivar Duncan grapefruit against $X$. citri subsp. citri. The bacterial isolates were previously isolated from the rhizosphere of citrus escape trees (healthy looking trees in severely Huanglongbing [HLB]-diseased groves) in Florida (Table 1).

Plant materials and treatments. For disease severity studies, 2-year-old Duncan grapefruit plants were used for $X$. citri subsp. citri inoculation or PGPR treatments. Plants were grown in small pots of $500 \mathrm{ml}$ with sterile soil. All plants were selected with the same age and with leaves of similar growth stage. Experiments were performed in a quarantine greenhouse facility (Citrus Research and Education Center, Lake Alfred, FL) under controlled temperature $\left(28\right.$ to $35^{\circ} \mathrm{C}$ ) and relative humidity of $80 \%$.

Five treatments were applied as soil drench to the root system 7 days before pathogen challenge in the leaves. The five treatments consisted in $15 \mathrm{ml}$ of suspension of (i) P. geniculata strain 95 (108 CFU/ml), (ii) B. territorii strain A63 $\left(10^{8} \mathrm{CFU} / \mathrm{ml}\right)$, (iii) B. metallica strain A53 (108 CFU/ml), (iv) $5 \mathrm{mg}$ of acibenzolarS-methyl (ASM) (active ingredient of Actigard 50WG in the United States and Bion in Europe), and (v) sterile distilled water as a negative control. ASM is a functional analog of SA and was used as a positive control of plant defense activation (Francis et al. 2009; Graham and Leite 2004). The experiment was repeated in January
2015 with five plants per treatment and in May 2015 with seven plants. Data from all 12 plants were combined for statistical analyses.

Eight-month-old Duncan grapefruit plants grown in 500-ml pots in sterile soil were used for gene expression analyses. Three treatments were applied in the same way as for disease severity, consisting of (i) P. geniculata, (ii) ASM, and (iii) sterile distilled water-inoculated plants. Five plants were inoculated per treatment during October 2017.

Reactive oxygen species and hormone analyses were conducted with 12 2-year-old Duncan grapefruit plants in October 2015. Treatments and soil drench application were conducted as described for gene expression analyses.

$X$. citri subsp. citri inoculation and disease severity estimation. Duncan grapefruit plants were challenged with $X$. citri subsp. citri strain $306\left(10^{8} \mathrm{CFU} / \mathrm{ml}\right)$ by spray inoculation postroot treatment with PGPR. Plants used for disease severity estimation and relative gene expression were challenge at day 7. For each plant, at least three fully expanded immature leaves were labeled and sprayed until fully covered with bacterial suspension. Plants were then covered with a plastic bag for $24 \mathrm{~h}$ to maintain humidity. Symptoms were monitored at 6 weeks post-pathogen inoculation. Labeled leaves were collected and pictures were taken immediately. Pictures were uniformly taken by setting the camera (Nikon D80) on a tripod and using a blank background at $30 \mathrm{~cm}$. To estimate disease severity, pictures were used for manual lesion count and image processing analysis.

Image processing analysis. The normalized area of disease was estimated using ImageJ (version 1.49). Recorded images from individual leaves were transformed to the HSB color space and further analyzed using two different macros. In the first step, the background was subtracted using the saturation channel and total leaf area was recorded. Secondly, two masks were applied to the hue channel, around the yellow color to specifically identify the lesions. Finally, the total area of lesions was recorded. The normalized area of disease per leaf was calculated as follows: Normalized area $=$ Area $_{\text {lesions }} /$ Area $a_{\text {leaf }}$.

RNA extraction and relative gene expression analysis. One leaf was collected for gene expression analysis from each of five different plants at the following time points: $3,5,8$, and 10 days post-treatment application in the root system. Days 8 and 10 represent the plant response after pathogen challenge at day 7. Individual leaves were then ground in liquid nitrogen using a mortar and pestle and then $100 \mathrm{mg}$ of leaf samples was used for RNA extraction. RNA was extracted using the RNeasy Mini Kit (QIAGEN) following the manufacturer's instructions. Samples were then treated with Ambion DNA-free DNase Treatment and Removal Reagents. RNA concentration was determined using a NanoDrop ND-1000 spectrophotometer (NanoDrop Technologies Inc., Wilmington, $\mathrm{DE})$, the final concentration was normalized to $50 \mathrm{ng} / \mu \mathrm{l}$ for quantitative reverse-transcription (qRT-PCR) analysis.

Relative expression of eleven defense-related genes was determined by qRT-PCR. The primer sequences are presented in Table 2. The housekeeping gene encoding a glyceraldehyde 3-phosphate dehydrogenase (GAPDH) was used as an endogenous control as previously described (Francis et al. 2009). qRT-PCR was performed using Verso 1-step RT-qPCR Kit (ThermoFisher). The relative fold change of target gene expression in $P$. geniculate- or

TABLE 1. Beneficial bacteria used for screening of induced systemic resistance ability

\begin{tabular}{|c|c|c|c|c|}
\hline Strain name & Origin & Host plant & Isolation year & Source or reference \\
\hline Burkholderia territorii strain A63 & Root-associated bacteria & Cleopatra mandarin & 2013 & (Riera et al. 2017) \\
\hline Burkholderia metallica strain A53 & Root-associated bacteria & Cleopatra mandarin & 2013 & (Riera et al. 2017) \\
\hline Pseudomonas geniculata strain 95 & Root-associated bacteria & Valencia orange & 2010 & (Trivedi et al. 2011) \\
\hline Rhodococcus jialingiae strain 108 & Root-associated bacteria & Valencia orange & 2010 & (Trivedi et al. 2011) \\
\hline Bacillus pumilus strain 104 & Root-associated bacteria & Valencia orange & 2010 & (Trivedi et al. 2011) \\
\hline Pseudomonas granadensis strain 100 & Root-associated bacteria & Valencia orange & 2010 & (Trivedi et al. 2011) \\
\hline
\end{tabular}


ASM-treated plants was calculated and normalized against its expression levels in water-treated plants, using the $\Delta \Delta \mathrm{Ct}$ method as previously described (Livak and Schmittgen 2001).

Plant hormones quantification and ROS determination. Plant hormones were quantified in the Duncan grapefruit plants at 0 , 3 , and 8 days post-treatment application in the root system. Three leaves from different plants were pooled together as one repeat and four repeats were tested. Plant tissue was kept in liquid nitrogen immediately after detaching from the plants. Tissue was ground into powder in a mortar and pestle in liquid nitrogen. The frozen powder was weighed and $100 \mathrm{mg}$ of frozen powder was kept in 2-ml screwcap tubes. Samples were kept in $-80^{\circ} \mathrm{C}$ for further analyses.

Hormones were extracted as previously described (Pan et al. 2010) and samples were cleaned up using solid phase extraction cartridge and quantified using UPLC-MS/MS. For phytohormone extraction and quantification the internal standard mixture working solution $\left(\mathrm{d}_{2}-\mathrm{IAA}, \mathrm{d}_{6}-\mathrm{ABA}, \mathrm{d}_{6}-\mathrm{SA}\right.$, and $\left.\mathrm{d}_{5}-\mathrm{JA}\right)$ was added to each 2$\mathrm{ml}$ tube containing the frozen plant tissue powder. Then, $500 \mu \mathrm{l}$ of extraction solvent was added (2-propanol/ $\mathrm{H}_{2} \mathrm{O} /$ concentrated $\mathrm{HCl}$ [2:1:0.002, vol/vol/vol]). The samples were shaken at a speed of $100 \mathrm{rpm}$ at $4^{\circ} \mathrm{C}$ in a cold room for $30 \mathrm{~min}$. Finally, $1 \mathrm{ml}$ of dichloromethane was added to the tubes and the tubes were further shaken at $4^{\circ} \mathrm{C}$ at $100 \mathrm{rpm}$ for $30 \mathrm{~min}$. Samples were then centrifuged at $13,000 \times g$ for $10 \mathrm{~min}$ at $4^{\circ} \mathrm{C}$. The lower phase solvent was transferred to a screw-cap tube and gently evaporated with nitrogen flow. Concentrated samples were dissolved in $1 \mathrm{ml}$ of methanol. Samples were cleaned in a solid phase extraction column (Oasis HLB 1 cc $30 \mathrm{mg}$ extraction cartridge, waters). Cartridges were equilibrated with $1 \mathrm{ml}$ water and loaded with $1 \mathrm{ml}$ of sample. Samples were eluted with $1 \mathrm{ml}$ methanol and evaporated with nitrogen flow. Concentrated samples were dissolved in methanol and filtered through $0.2 \mu \mathrm{m}$ filter before analysis. For each sample, $50 \mu \mathrm{l}$ of sample solution was injected into the reverse-phase $\mathrm{C}_{18}$ HPLC column Synergi for UPLC-ESI-MS/MS analysis using an Ultimate 3000 UPLC with a TSQ Quantiva MS. For each treatment, the relative hormone levels were normalized with the mean value for day 0 prior to treatment application.

For ROS determination, the fluorescent dye DHR 123 (dihydrorhodamine) was used as previously described with modifications
(Qin et al. 2008). Briefly, extraction buffer (50 mM Tris $\mathrm{pH}=7.8$, 5 mM EDTA, $0.2 \%$ Triton $100 \mathrm{X}, 10 \%$ glycerol, 5 mM DTT, and $2 \%$ PVPP) was added to $100 \mathrm{mg}$ of ground tissue. Samples were then centrifuged at 15,000 rpm for $30 \mathrm{~min}$. Following centrifugation, $900 \mu \mathrm{l}$ of dihydrorhodamine 123 probe (dihydrorhodamine 123, Sigma-Aldrich, Inc.) was added to $100 \mu \mathrm{l}$ of supernatant. The obtained solution was incubated at room temperature for $1 \mathrm{~h}$ in the dark and fluorescence was determined in three technical repeats at $488 \mathrm{~nm}$ excitation and $534 \mathrm{~nm}$ emission in a Synergy HT MultiMode Microplate Reader (Biotek Instruments Inc.). Each tube was kept at $60^{\circ} \mathrm{C}$ in a stove and dry weight was determined for further calculations.

Statistical analysis. Disease severity (normalized area of disease and lesion count) data were analyzed using R Studio (Version 0.98.1049, 2009-2013 R Studio, Inc.) by applying Dunn's test (package: dunn.test) with a $P$ value of 0.05 or less. Hormone levels data were analyzed with R Studio using analysis of variance and Tukey's honest significant difference test posthoc with a confidence interval of $95 \%$ and a $P$ value of 0.05 or less (ANOVA, Tukey's HSD). ROS production on leaves data were analyzed with Microsoft Excel using Student's $t$ tests on all pairs with a confidence interval of $95 \%$ and $P<0.05$.

\section{RESULTS}

Bacteria application in the root reduced citrus canker development. To screen for beneficial bacteria capable of activating citrus immunity, we inoculated seven bacterial isolates (Table 1) in the root system via soil drench and allowed the plant to respond for 7 days. After 1 week, young leaves of Duncan grapefruit plants were spray inoculated with $X$. citri subsp. citri strain 306. In addition to bacterial treatments we included the chemical treatment ASM as a positive control of defense activation. ASM has been previously reported to induce citrus systemic resistance against canker (Francis et al. 2009).

Disease severity was quantified using two independent measurements: (i) by counting the number of lesions per leaf and (ii) by estimating the total area of disease. Estimation of lesion count when the pathogen is sprayed on the leaves has two major limitations: the

TABLE 2. Primers used for expression analysis of plant defense genes

\begin{tabular}{|c|c|c|c|c|}
\hline Short name & Protein encoded & Primers $\left(5^{\prime}-3^{\prime}\right)$ & Reference & Proposed pathway \\
\hline HPL1 & Fatty acid hydroperoxide lyase & F-AGTGTGCCGGAAAGGATTAC & This study & $\begin{array}{l}\text { Production of C6 volatiles or } \\
\text { green leaf volatiles, } \\
\text { derived from LOX } \\
\text { pathway }\end{array}$ \\
\hline GPX & $\begin{array}{l}\text { Phospholipid hydroperoxide } \\
\text { glutathione peroxidase }\end{array}$ & $\begin{array}{l}\text { R-GCCGTGATCGAAGATGAGTT } \\
\text { F-TGTGCAAGTCGTTACCTTCTTA } \\
\text { R-TCTCAACAGGGTTTGCTTACA }\end{array}$ & This study & ROS response \\
\hline NPR1 & $\begin{array}{l}\text { Transcriptional regulator of } \\
\text { defense genes }\end{array}$ & $\begin{array}{l}\text { F-GTAGGCCGGCTGTTGATTT } \\
\text { R-GTCTAGGAGGTGCCTCTGATAA }\end{array}$ & This study & SA and JA/ET pathway \\
\hline MYC & Transcriptional regulator $\mathrm{MYC} 2$ & $\begin{array}{l}\text { F-GCGATGGGTATTACAAAGGAGA } \\
\text { R-TTCGCGCAGTACCTTCTTAC }\end{array}$ & This study & JA/ET pathway \\
\hline PR1 & Pathogenesis-related protein 1 & $\begin{array}{l}\text { F-CAGGGTCTCCAAGCAACTATG } \\
\text { R- CCACCTCGCGTATTTCTCTAA }\end{array}$ & (Zhang et al. 2017) & SA pathway \\
\hline PR2 & Pathogenesis-related protein 2 & $\begin{array}{l}\text { F-TTCCACTGCCATCGAAACTG } \\
\text { R-TGTAATCTTGTTTAAATGAGCCTCTTG }\end{array}$ & (Francis et al. 2009) & SA pathway \\
\hline PR5 & Pathogenesis-related protein 5 & $\begin{array}{l}\text { F-CACCATTGCCAATAACCCTAATG } \\
\text { R-GGGACAGTTACCGTTAAGATCAG }\end{array}$ & This study & SA pathway \\
\hline PAL & Phenylalanine ammonia lyase & $\begin{array}{l}\text { F-GGAGGGTTTGTGCAAGAATAAC } \\
\text { R-CACCATACGCTTCACTTCCT }\end{array}$ & This study & SA and JA/ET pathway \\
\hline SAM-SACM & $\begin{array}{l}\text { S-adenosyl-L-methionine-salicylic } \\
\text { acid carboxyl methyltransferase }\end{array}$ & $\begin{array}{l}\text { F-GGACGCATCTTCTTGGGATAA } \\
\text { R-CGTGACAGTTTCCTTGACGA }\end{array}$ & (Zhang et al. 2017) & MeSA synthesis \\
\hline MPK4 & Mitogen-activated protein kinase 4 & $\begin{array}{l}\text { F-GTTGGTTGCATACTTGGTGAAA } \\
\text { R-GCATCATCGGGAGAACCTATT }\end{array}$ & This study & SA pathway \\
\hline CAT & Catalase & $\begin{array}{l}\text { F-GGAAACCAACTTGTGGAGTTAAG } \\
\text { R-TGAGTCGTAGAGATCCTGAGTAG }\end{array}$ & This study & \\
\hline GAPDH & $\begin{array}{l}\text { Glyceraldehyde 3-phosphate } \\
\text { dehydrogenase }\end{array}$ & $\begin{array}{l}\text { F-GGAAGGTCAAGATCGGAATCAA } \\
\text { R-CGTCCCTCTGCAAGATGACTCT }\end{array}$ & (Francis et al. 2009) & Housekeeping gene \\
\hline
\end{tabular}


variability of the lesion size in different leaves and the aggregation of some lesions that makes it hard to discriminate individual counts. To improve this estimation, we used the same pictures and estimated the area of disease with image processing analysis using ImageJ software. According to both measurements, three bacterial strains, B. territorii strain A63, B. metallica strain A53, and $P$. geniculata strain 95 , significantly reduced the canker disease severity in Duncan grapefruit (Fig. 1B and C). No significant differences were observed in plants inoculated with $P$. granadensis strain 100, Rhodococcus jialingiae strain 108, or Bacillus pumilus strain 104 compared with nontreated control plants (data not shown).

Beneficial bacteria trigger changes in expression of defense-related genes. Activation of citrus systemic immunity has been linked to the overexpression of certain defense-related genes (Distefano et al. 2008; Dutt et al. 2015; Francis et al. 2009; Li et al. 2016). We evaluated if the application of beneficial bacteria in the root system could activate expression of defense-related genes systemically. We collected leaf tissues during the first week after beneficial bacteria inoculation (days 3 and 5) prior to $X$. citri subsp. citri challenge and after (days 8 and 10). We monitored the expression of 11 selected genes and compared the relative expression to nontreated plants. The expression of ASM-treated plants was also included as a positive control of plant defense activation. Among the selected genes we selected markers from both SA and lipoxygenase pathways of plant immunity (Table 2).

Since both Burkholderia strains used in this study belong to the B. cepacia complex (BCC), a group with known opportunistic human pathogens, we decided to focus on $P$. geniculata for further study. Bacterial treatments with $P$. geniculata strain 95 and the chemical ASM caused differential expression of defense-related genes from nontreated control plants. The bacterial treatment with $P$. geniculata strain 95 up-regulated the expression of the salicylic acid carboxyl methyltransferase (SAM-SACM) and the pathogenesis-related proteins 1, 2, and 5 (PR1, PR2, and PR5) during the priming phase (days 3 and 5) (Table 3). Similarly, ASM application up-regulated the expression of PR2 and PR5 in the plants before pathogen challenge (Table 3). Specifically, P. geniculata strain 95 induced stronger gene expression of SAM-SACM and PR1 than ASM during the priming phase (days 3 and 5). PR proteins and SAM-SACM are normally related to the activation of the SA pathway. In addition, MAPK4 levels were down-regulated at day 8 for ASM $(0.53 \pm 0.097)$ and $P$. geniculata $(0.42 \pm 0.22)$ treated plants. MAPK4 is a negative regulator of SA pathway (Loake and Grant 2007), further suggesting that a SA-mediated response is being activated. Additionally, we found SAM-SACM with a 25-fold increase in ASM-treated plants at day 10 post-treatment application. The enzyme is involved in the synthesis of methyl salicylate, an important signaling molecule in
A

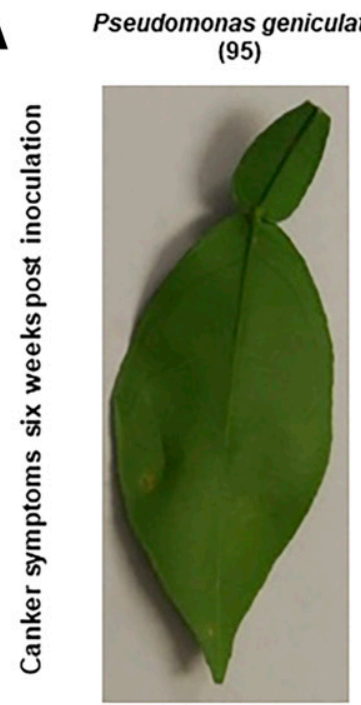

Burkholderia metallica (A53)

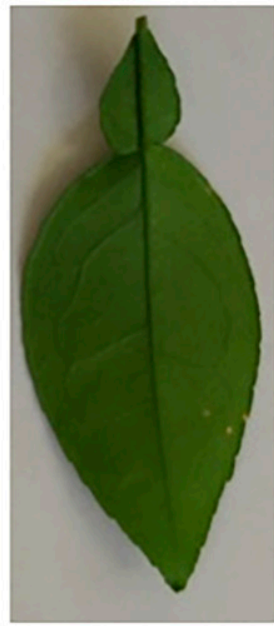

Burkholderia territori (A63)

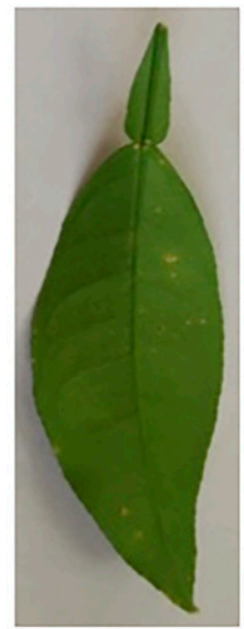

Actigard 50 WG

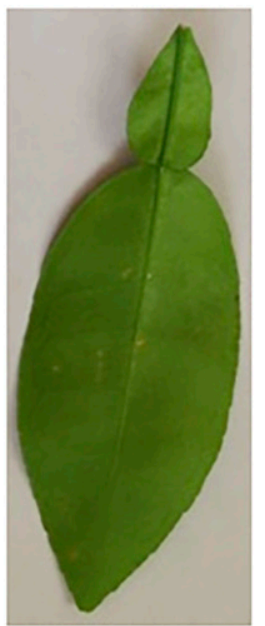

Water Control

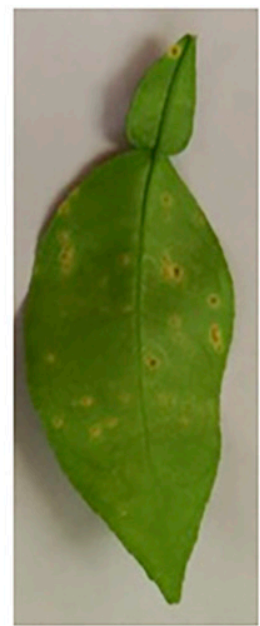

B

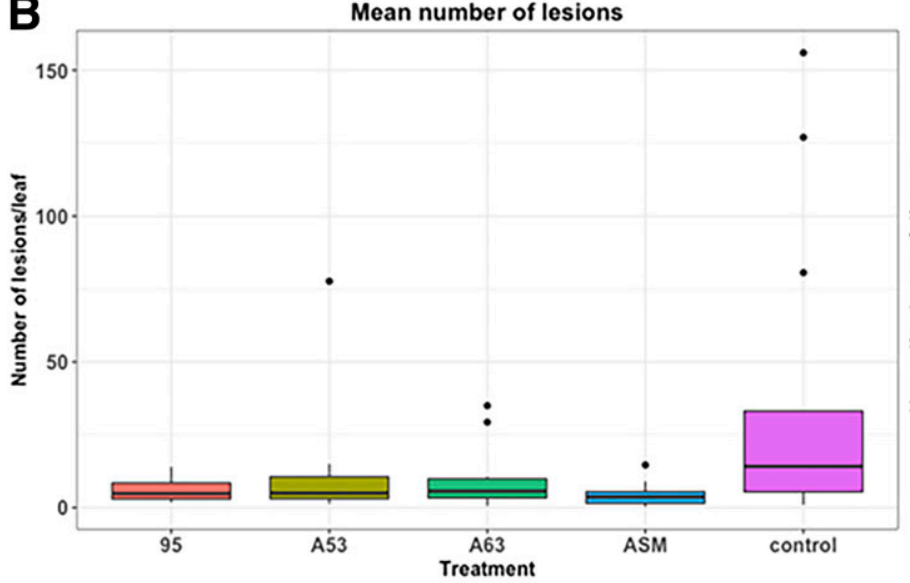

C

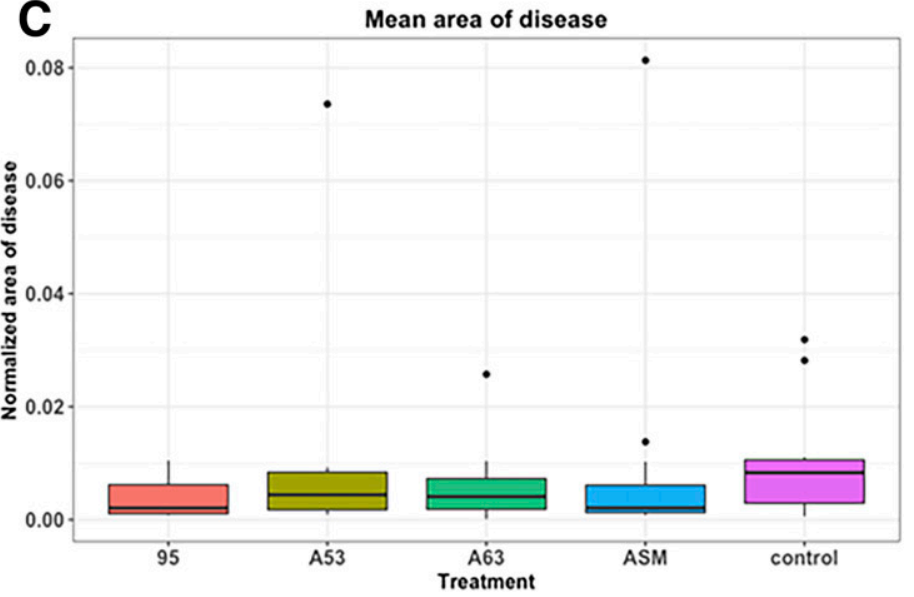

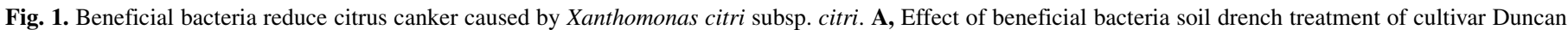

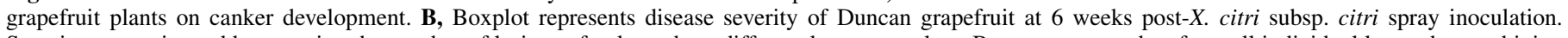

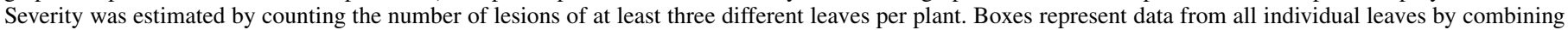

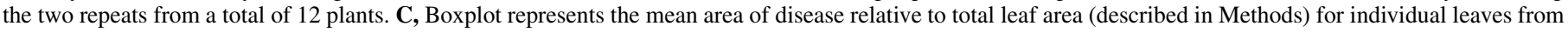

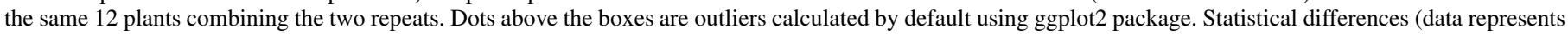

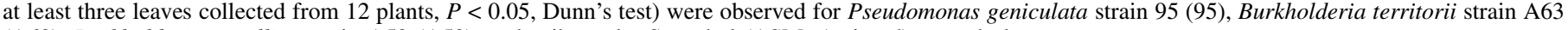
(A63), Burkholderia metallica strain A53 (A53), and acibenzolar-S-methyl (ASM; Actigard)-treated plants. 
plant defense (Park et al. 2007). After spray inoculation with the pathogen at day 8, P. geniculata strain 95-treated plants showed increased levels of phenylalanine ammonia lyase 1 (PAL) and SAMSACM genes. Higher expression of SAM-SACM and PR2 was also observed in the ASM-treated plants during the post-X. citri subsp. citri inoculation phase.

$P$. geniculata modulates hormone and ROS levels in grapefruit. Plants stimulated with a proper signal enter a different physiological state named priming phase (Balmer et al. 2015). In this state, plants can respond faster to pathogen attack. We investigated two putative mechanisms involved in plant defense activation: the production of reactive oxygen species and hormone in the leaf tissue. In both cases, we studied the aerial response of $P$. geniculata-inoculated plants during the 1-week period post-root stimulation. For hormone and ROS analyses, we included ASMtreated plants in the comparison. We observed that plants inoculated with $P$. geniculata had significantly higher levels of ROS than nontreated control plants at 8 days post-beneficial bacteria root inoculation (Fig. 2). Plants inoculated with ASM showed similar ROS levels with those treated by $P$. geniculata, but not significantly higher than the control at 8 days post-treatment inoculation. However, the ASM-treated plants had significantly higher levels of ROS than the control at 5 days post-treatment application (Fig. 2).

Nontreated control plants contained lower levels of IAA compared with plants treated with ASM or P. geniculata at 3 and 8 days after treatment (Fig. 3). The levels of ABA at 8 days poststimuli application were significantly lower in $P$. geniculata-treated plants but significantly higher in ASM-treated plants than nontreated control plants. The plants treated with ASM showed lower levels of SA 3 days post-application than nontreated control plants. $\mathrm{SA}$ is the substrate for the S-adenosyl-L-methionine-salicylic acid carboxyl methyltransferase (SAM-SACM) an enzyme that converts the hormone in its conjugate form methyl salicylate (MeSA).

\section{DISCUSSION}

Inducing systemic plant defense response by beneficial bacteria in citrus plants remains largely unexplored. Agostini et al. (2003) evaluated the effect of Serenade (biological fungicide based on Bacillus subtilis strain QST 713) inoculation in reducing disease severity of citrus scab on rough lemon, melanose on grapefruit, and Alternaria brown spot in mandarin under greenhouse conditions (Agostini et al. 2003). However, it is unclear whether the control effect was due to the activation of systemic resistance or direct antagonism of the bacterial strain. In this study, we inoculated the beneficial bacteria in the root system as soil drench and evaluated the effect on leaf pathogen $X$. citri subsp. citri to avoid any direct competition between beneficial and pathogenic bacteria. Treatments with $B$. metallica, B. territorii, and P. geniculata have significantly reduced canker development on Duncan grapefruit plants, suggesting an activation of plant defense responses.

The expression profile of Duncan grapefruit plants changed upon root stimulation with the beneficial bacteria $P$. geniculata as well as the chemical elicitor ASM. P. geniculata stimulated an upregulation of SAM-SACM and PR proteins genes. PR1, PR2, and PR5 are usually considered as markers associated with SA signaling pathway. In this work, the relative gene expression of PAL and SAM-SACM genes increased after pathogen challenge (day 8) in P. geniculata-treated plants 4.8 and 2.5 times compared with control plants. For ASM-treated plants in the post-challenge prime state at day 10, SAM-SACM and PR2 genes were up-regulated 25.8 and 3.7 times, respectively. The increased relative levels of SAM-SACM, PAL, or PR2 transcripts post-pathogen inoculation suggest that the priming state is achieved by ASM and $P$. geniculata root application. In comparison, the changes in gene expression after pathogen challenge in $P$. geniculata-treated plants was less than that observed for ASM-treated plants at 8 and 10 days. It is worth noting that changes in disease severity were comparable 6 weeks post$X$. citri subsp. citri challenge, suggesting that bacteria application may be slower but as effective as that induced by the SA analog ASM. A possible explanation could be the ability of rhizospheric bacteria to proliferate in the rhizosphere in contrast with a chemical compound (such as ASM). The relative expression of PAL gene was

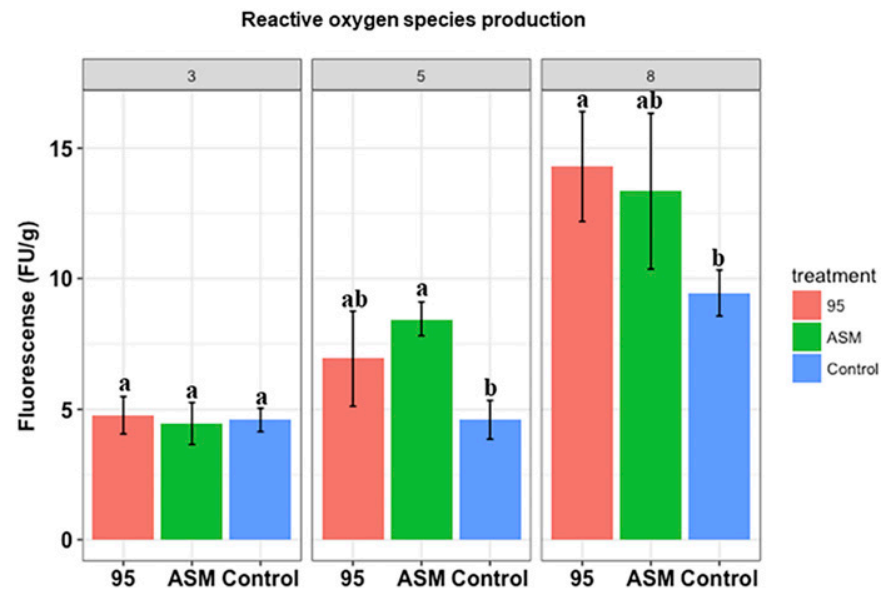

Fig. 2. Reactive oxygen species (ROS) levels in leaves treated with Pseudomonas geniculata strain 95, acibenzolar-S-methyl (ASM), or nontreated control. The three facets represent ROS levels at days 3, 5, and 8 per root treatment application using DHR123 probe. Bars represent the mean relative fluorescence value and error bars (standard error). Letters indicate significant differences between treatments $(n=4$, Student's $t$ tests on all pairs with a $95 \%$ confidence interval and $P<0.05)$

TABLE 3. The relative gene expression of target genes in Pseudomonas geniculate or acibenzolar-S-methyl (ASM)-treated grapefruit plants ${ }^{\mathrm{z}}$

\begin{tabular}{|c|c|c|c|c|c|c|c|c|}
\hline \multirow[b]{2}{*}{ Gene } & \multicolumn{2}{|c|}{ Day 3} & \multicolumn{2}{|c|}{ Day 5} & \multicolumn{2}{|c|}{ Day 8} & \multicolumn{2}{|c|}{ Day 10} \\
\hline & P. geniculata & ASM & P. geniculata & ASM & P. geniculata & ASM & P. geniculata & ASM \\
\hline CAT & $1.27(0.225) \mathrm{a}$ & $1.11(0.068) \mathrm{a}$ & $1.12(0.096) \mathrm{b}$ & $1.51(0.132) \mathrm{a}$ & $0.75(0.0863) b$ & $1.19(0.068) \mathrm{a}$ & $0.53(0.120) \mathrm{b}$ & $0.82(0.090) \mathrm{a}$ \\
\hline GPX & $1.01(0.239) \mathrm{a}$ & $0.61(0.038) b$ & $0.56(0.065) \mathrm{b}$ & $0.78(0.106) \mathrm{a}$ & $0.58(0.096) b$ & $0.85(0.059) \mathrm{a}$ & $0.77(0.070) \mathrm{b}$ & $1.06(0.039) \mathrm{a}$ \\
\hline MPK4 & $1.29(0.318) \mathrm{a}$ & $0.75(0.120) b$ & $0.88(0.279) \mathrm{a}$ & $0.59(0.075) \mathrm{a}$ & $0.42(0.220) \mathrm{a}$ & $0.53(0.097) \mathrm{a}$ & $0.81(0.189) \mathrm{a}$ & $0.74(0.132) \mathrm{a}$ \\
\hline MYC & $1.31(0.332) \mathrm{a}$ & $0.69(0.135) \mathrm{b}$ & $1.46(0.092) \mathrm{a}$ & $0.58(0.146) \mathrm{b}$ & $0.98(0.241) \mathrm{a}$ & $0.80(0.101) \mathrm{a}$ & $0.83(0.047) \mathrm{a}$ & $0.86(0.066) \mathrm{a}$ \\
\hline NPR1 & $1.05(0.127) \mathrm{a}$ & $1.06(0.020) \mathrm{a}$ & $0.94(0.232) \mathrm{a}$ & $1.21(0.082) \mathrm{a}$ & $0.55(0.041) b$ & $0.67(0.062) \mathrm{a}$ & $0.87(0.220) \mathrm{b}$ & $1.69(0.103) \mathrm{a}$ \\
\hline SAM-SACM & $2.82(0.206) \mathrm{a}$ & $2.50(0.098) \mathrm{a}$ & $2.09(0.234) \mathrm{a}$ & $1.42(0.157) \mathrm{b}$ & $2.50(0.235) \mathrm{a}$ & $0.53(0.081) b$ & $1.46(0.341) \mathrm{b}$ & $25.84(0.269) \mathrm{a}$ \\
\hline HPL & $0.47(0.210) \mathrm{b}$ & $0.85(0.018) \mathrm{a}$ & $0.98(0.176) \mathrm{a}$ & $1.24(0.399) \mathrm{a}$ & $0.67(0.235) b$ & $1.85(0.254) \mathrm{a}$ & $1.46(0.100) \mathrm{a}$ & $1.51(0.085) \mathrm{a}$ \\
\hline PAL & $1.66(0.124) \mathrm{a}$ & $0.75(0.038) b$ & $0.82(0.107) \mathrm{a}$ & $0.22(0.147) b$ & $4.79(0.175) \mathrm{a}$ & $0.61(0.049) \mathrm{b}$ & $0.75(0.062) \mathrm{a}$ & $0.64(0.029) \mathrm{a}$ \\
\hline PR1 & $2.22(0.167) \mathrm{a}$ & $1.08(0.027) \mathrm{b}$ & $2.29(0.118) \mathrm{a}$ & $0.24(0.270) b$ & $0.32(0.079) \mathrm{a}$ & $0.45(0.121) \mathrm{a}$ & $1.15(0.054) \mathrm{a}$ & $0.50(0.064) b$ \\
\hline PR2 & $2.14(0.049) \mathrm{b}$ & $4.24(0.141) \mathrm{a}$ & $1.83(0.141) b$ & $6.06(0.132) \mathrm{a}$ & $1.94(0.185) b$ & $4.11(0.095) \mathrm{a}$ & $1.55(0.132) b$ & $3.72(0.099) \mathrm{a}$ \\
\hline PR5 & $2.78(0.380) \mathrm{a}$ & $2.18(0.250) \mathrm{a}$ & $0.29(0.011) \mathrm{a}$ & $0.05(0.010) b$ & $0.34(0.030) \mathrm{a}$ & $0.27(0.023) \mathrm{a}$ & $1.59(0.052) \mathrm{a}$ & $0.27(0.036) b$ \\
\hline
\end{tabular}

$\mathrm{z}$ The relative fold change of target gene expression in $P$. geniculate- or ASM-treated plants was calculated and normalized against its expression levels in watertreated plants. Values were shown as mean fold change (standard error) $(n=5)$. Different letters in the same row indicate significant differences between treatments at the same time points (Student's $t$ test, $P<0.05$ ). Time points selected were before (days 3 and 5 ) and after (days 8 and 10) pathogen challenge. 
4.8-fold upregulated at 8 days post-treatment with $P$. geniculata. The PAL gene encodes a phenylalanine ammonia lyase, which is the entry point enzyme in the phenylpropanoid pathway. Phenylpropanoids play a key role in the protection of plants against biotic and abiotic stress (Mierziak et al. 2014). For example, PAL catalyzes the production of trans-cinnamic acid from L-phenylalanine (Hahlbrock and Scheel 1989). Trans-cinnamic acid is a precursor in the phenylpropanoid pathways of plant defense and is believe to be activated by JA/ET signaling pathway (Diallinas and Kanellis 1994). In addition, trans-cinnamic acid can also serve as a precursor in the synthesis of SA, and it has been reported to have a role in the accumulation of SA in response to pathogen recognition in some plants (Mauch-Mani and Slusarenko 1996; Pallas et al. 1996; Shine et al. 2016). It has long been considered that SA accumulation upon biotic and abiotic stress in plants was produced mainly through the isochorismate synthase pathway. In citrus, how much each pathway contributes to total SA remains unknown (Catinot et al. 2008; Garcion et al. 2008; Wildermuth et al. 2001). However, we did not observe major changes in SA content in treated versus nontreated plants. The mechanisms by which beneficial bacteria activate systemic resistance in plants are diverse. Some bacteria are able to induce systemic resistance through activating the SA-dependent defense pathway (van de Mortel et al. 2012), some through the ET/ JA signaling pathway (Pieterse et al. 1998), whereas some bacteria induce both (Niu et al. 2011). Recently, the induced systemic resistance (ISR)-eliciting beneficial strain Bacillus cereus AR156 has been shown to induce PR1 protein expression through SApathway through NPR1, inducing ROS levels compared with nontreated plants (Niu et al. 2016). In our study, we did not find any change of NPR1 relative expression in beneficial bacteria or ASMtreated plants.
After the recognition of a proper priming stimulus, plants undergo physiological changes that allow for the stronger and faster defense response upon pathogen challenge (reviewed in Balmer et al. 2015). Typically, induction of the physiological state involves changes in primary metabolism including sugars, amino acids, tricarboxylic acid metabolites as well as a burst in ROS and upregulation of defense related genes (Balmer et al. 2015; Pastor et al. 2014). ROS species are produced as part of the plant defense response. In SA-dependent defense, it has been proposed that ROS is involved in the production of AzA, a signal molecule associated with triggering the systemic acquire resistance (SAR) response (Wang et al. 2014; Wendehenne et al. 2014). We observed that root application of ASM and P. geniculata in grapefruit plants results in an increase in ROS levels in aerial tissues compared with nontreated control plants. Activation of ROS by beneficial bacteria has been reported in Nicotiana tabacum agroinfiltrated with Agrobacterium tumefaciens GV3101 and in barley treated with P. fluorescens. ROS pathway was proposed in both cases to be part of the plant defense mechanism resulting in defense activation against P. syringae and Fusarium culmorum (Petti et al. 2010; Sheikh et al. 2014).

$P$. geniculata application on grapefruit roots altered the levels of plant hormones in the leaves. $P$. geniculata application resulted in an increase of IAA compared with noninoculated control plants. IAA accumulation was also reported in Arabidopsis thaliana treated with $P$. syringae (Pastor et al. 2014). In ASM-treated plants, we observed that the IAA levels decreased at day 3 but significantly lesser than the decrease observed in nontreated control plants. IAA levels in priming events have been associated with changes in primary metabolism and tryptophan pathway. Additionally, we found that $\mathrm{ABA}$ levels were significantly lower in grapefruit at
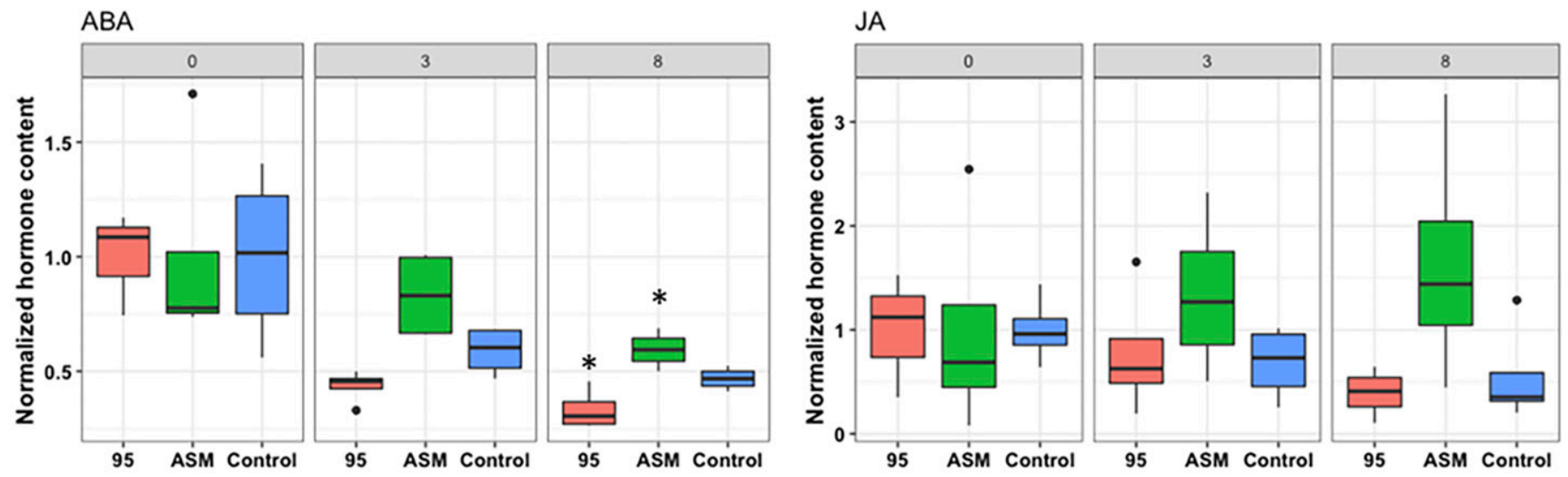

SA
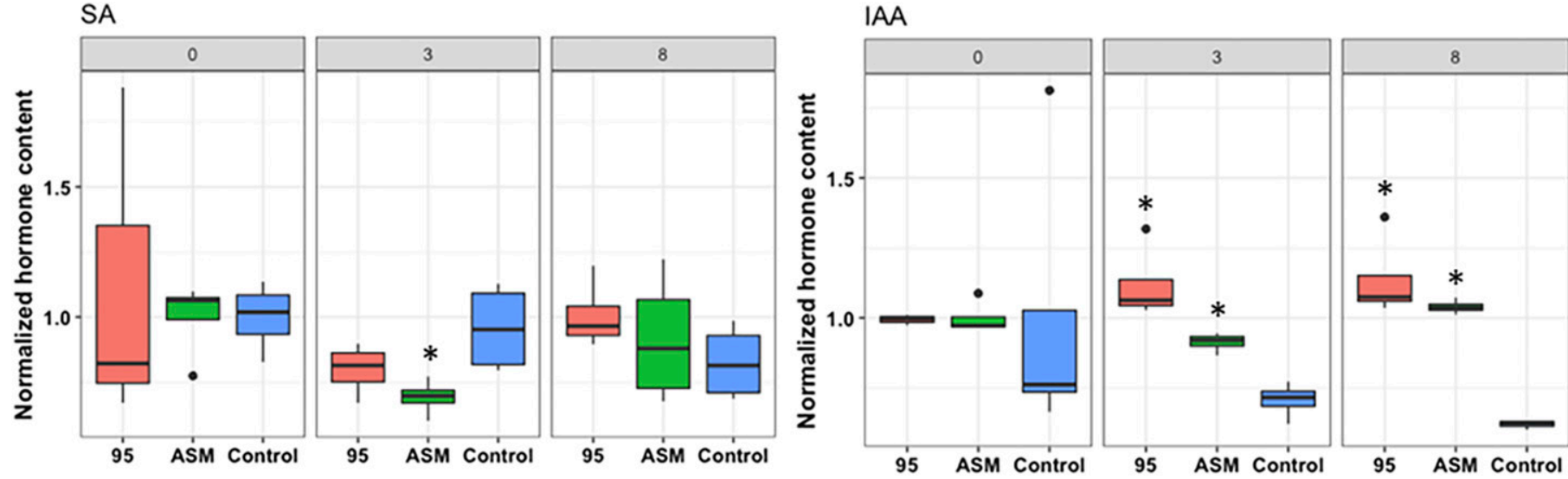

Fig. 3. Boxplot with the normalized hormone content in leaf tissue of cultivar Duncan grapefruit plants treated with Pseudomonas geniculata strain 95 (95), acibenzolar-S-methyl (ASM; Actigard) and nontreated control. Hormones were extracted and quantified by UPLC-ESI-MS/MS analysis at days 0, 3, and 8 per root treatment application. Dots represent outliers calculated by default with ggplot2 package. Samples were analyzed with an analysis of variance test followed with a Tukey honest significant differences posthoc (letters indicate a $P$ value $<0.05, n=4$, confidence interval $95 \%$ ). 
8 days post- $P$. geniculata inoculation. In contrast, ABA levels showed an opposite effect in ASM-treated plants compared with the nontreated counterparts. ABA is a key stress hormone in plants that has a dual activity in plant-pathogen interactions that range from promoting resistance to increasing susceptibility. ABA may have an active role in the early stages of defense but a suppressive role in late stages. Overall, it has been proposed that the effect of ABA in defense against bacterial pathogens is mostly negative (Ton et al. 2009). For instance, callose deposition, an important defense mechanism in plants, was shown to be suppressed by ABA in A. thaliana (Clay et al. 2009). $P$. geniculata inoculation in grapefruit plants results in over expression of PR-protein and SAM-SACM genes which are dependent on the SA pathway. However, we noted that the levels of SA were not significantly different from those of control plants. The same pattern was observed for ASM-treated plants, with a decrease in SA observed at 3 days post-treatment application. Additionally, the increased transcript levels of SAM-SACM in ASM-treated plants at 3 days may suggest that the observed decrease in SA may be due to the production of MeSA, an important systemic signal in plant immune response (Park et al. 2007). However, results are not strictly comparable and should be treated with caution because gene expression data were from plants aged 8 months while hormonal analyses was from plants aged 2 years.

The plant response evoked in the initial stages of priming is thought to be mild compared with the post-challenge phase after pathogen encounter (Balmer et al. 2015). P. putida KT2440 inoculation in the roots evokes few changes in gene expression in both local and distal tissues in maize (Planchamp et al. 2015). Similarly, application of the ISR-eliciting strain Trichoderma asperellum in Arabidopsis thaliana roots results in very few changes in the priming phase. Based on the transcriptomic profiling using qRTPCR, only eight genes were significantly different out of 137 tested defense-related genes compared with nontreated control plants (Brotman et al. 2012). Here, we show that some root-associated bacteria are able to change citrus defense response by a series of physiological changes and that these can be effective against $X$. citri subsp. citri. Based on the current results, our selected ISR-eliciting strains could be triggering SA pathway of plant defense. Based on our current data, the activation of ET/JA pathway cannot be excluded as PAL1 may be activated by this pathway in the context of induced plant defense (Diallinas and Kanellis 1994). Further studies should be made to confirm whether ET/JA pathway is actually involved. In light of these results, it would be worth exploring the role of beneficial bacteria inoculation in other diseases caused by other bacteria and pathogenic fungi. Because of the lack of literature regarding citrus systemic resistance induced by beneficial bacteria, this work presents a first step in a largely unexplored field.

Conclusions. In this study, the ability of rhizospheric beneficial bacteria to activate citrus plant immunity and prime them against canker was explored. Three bacteria, B. metallica strain A53, $B$. territorii strain A63, and P. geniculata strain 95, were able to significantly decrease canker symptoms of Duncan grapefruit when inoculated via soil drench. $P$. geniculata inoculation induces changes of expression of defense-related genes, phytohormones IAA and ABA, and ROS levels, suggesting that a physiological effect is induced. Due to the adverse environmental effects of chemical control of citrus canker, the exploitation of environmentally friendly strategies represents an attractive approach to develop new control measures. The bacteria presented in this study could be potentially used to manage citrus canker disease and other bacterial diseases.

\section{ACKNOWLEDGMENTS}

We thank Y. Wang for the plant hormone quantification analysis; M. Andrade and D. Teper for carefully reading this manuscript and their valuable suggestions; and Dr. Etxeberria for providing the equipment for ROS detection assays.

\section{LITERATURE CITED}

Agostini, J. P., Bushong, P. M., and Timmer, L. W. 2003. Greenhouse evaluation of products that induce host resistance for control of scab, melanose, and Alternaria brown spot of citrus. Plant Dis. 87:69-74.

Alva, A. K. 1993. Copper contamination of sandy soils and effects on young Hamlin orange trees. Bull. Environ. Contam. Toxicol. 51:857-864.

Alva, A. K., Graham, J. H., and Anderson, C. A. 1995. Soil pH and copper effects on young "Hamlin". Orange Trees. Soil Sci. Soc. Am. J. 59:481-487.

Balmer, A., Pastor, V., Gamir, J., Flors, V., and Mauch-Mani, B. 2015. The "prime-ome": Towards a holistic approach to priming. Trends Plant Sci. 20: 443-452.

Barriuso, J., Solano, B. R., and Gutiérrez Mañero, F. J. 2008. Protection against pathogen and salt stress by four plant growth-promoting rhizobacteria isolated from Pinus sp. on Arabidopsis thaliana. Phytopathology 98:666-672.

Behlau, F., Hong, J. C., Jones, J. B., and Graham, J. H. 2012. Evidence for acquisition of copper resistance genes from different sources in citrusassociated xanthomonads. Phytopathology 103:409-418.

Brotman, Y., Lisec, J., Meret, M., Chet, I., Willmitzer, L., and Viterbo, A. 2012. Transcript and metabolite analysis of the Trichoderma-induced systemic resistance response to Pseudomonas syringae in Arabidopsis thaliana. Microbiology 158:139-146.

Catinot, J., Buchala, A., Abou-Mansour, E., and Métraux, J.-P. 2008. Salicylic acid production in response to biotic and abiotic stress depends on isochorismate in Nicotiana benthamiana. FEBS Lett. 582:473-478.

Clay, N. K., Adio, A. M., Denoux, C., Jander, G., and Ausubel, F. M. 2009. Glucosinolate metabolites required for an Arabidopsis innate immune response. Science 323:95-101.

Diallinas, G., and Kanellis, A. K. 1994. A phenylalanine ammonia-lyase gene from melon fruit: cDNA cloning, sequence and expression in response to development and wounding. Plant Mol. Biol. 26:473-479.

Distefano, G., Malfa, S. L., Vitale, A., Lorito, M., Deng, Z., and Gentile, A. 2008. Defense-related gene expression in transgenic lemon plants producing an antimicrobial Trichoderma harzianum endochitinase during fungal infection. Transgenic Res. 17:873-879.

Dutt, M., Barthe, G., Irey, M., and Grosser, J. 2015. Transgenic citrus expressing an Arabidopsis NPR1 gene exhibit enhanced resistance against Huanglongbing (HLB; citrus greening). PLoS One 10:e0137134.

Eisler, R. 1998. Copper hazards to fish, wildlife, and invertebrates: A synoptic review. U.S. Geological Survey, Biological Resources Division, Biological Science Report USGS/BRD/BSR-1997-0002.

Francis, M. I., Redondo, A., Burns, J. K., and Graham, J. H. 2009. Soil application of imidacloprid and related SAR-inducing compounds produces effective and persistent control of citrus canker. Eur. J. Plant Pathol. 124:283-292.

Garcion, C., Lohmann, A., Lamodière, E., Catinot, J., Buchala, A., and Doermann, P. 2008. Characterization and biological function of the ISOCHORISMATE SYNTHASE2 gene of Arabidopsis. Plant Physiol. 147:1279-1287.

Graham, J. H., and Leite, R. P. 2004. Lack of control of citrus canker by induced systemic resistance compounds. Plant Dis. 88:745-750.

Graham, J. H., Leite, R. P., Yonce, H. D., and Myers, M. 2008. Streptomycin controls citrus canker on sweet orange in Brazil and reduces risk of copper burn on grapefruit in Florida. Proc. Fla. State Hortic. Soc. 121:118-123.

Graham, J. H., and Myers, M. E. 2013. Integration of soil applied neonicotinoid insecticides and acibenzolar-S-methyl for systemic acquired resistance (SAR) control of citrus canker on young citrus trees. Crop Prot. 54: 239-243.

Graham, J. H., and Myers, M. E. 2016. Evaluation of soil applied systemic acquired resistance inducers integrated with copper bactericide sprays for control of citrus canker on bearing grapefruit trees. Crop Prot. 90:157-162.

Hahlbrock, K., and Scheel, D. 1989. Physiology and molecular biology of phenylpropanoid metabolism. Annu. Rev. Plant Physiol. Plant Mol. Biol. 40:347-369.

Lucas, J. A., Ramos Solano, B., Montes, F., Ojeda, J., and Megias, M., and Gutierrez Mañero, F. J. 2009. Use of two PGPR strains in the integrated management of blast disease in rice (Oryza sativa) in Southern Spain. Field Crops Res. 144:404-410.

Hu, J., Jiang, J., and Wang, N. 2018. Control of citrus Huanglongbing via trunk injection of plant defense activators and antibiotics. Phytopathology 108: 186-195.

Kuć, J. 1982. Induced immunity to plant disease. Bioscience 32:854-860.

Li, J., Pang, Z., Trivedi, P., Zhou, X., Ying, X., Jia, H., and Wang, N. 2017. 'Candidatus Liberibacter asiaticus' encodes a functional salicylic acid (SA) hydroxylase that degrades SA to suppress plant defenses. Mol. PlantMicrobe Interact. 30:620-630.

Li, J., Trivedi, P., and Wang, N. 2016. Field evaluation of plant defense inducers for the control of citrus Huanglongbing. Phytopathology 106:37-46.

Livak, K. J., and Schmittgen, T. D. 2001. Analysis of relative gene expression data using real-time quantitative PCR and the 2(-Delta Delta C(T)) method. Methods 25:402-408. 
Loake, G., and Grant, M. 2007. Salicylic acid in plant defence-the players and protagonists. Curr. Opin. Plant Biol. 10:466-472.

Mauch-Mani, B., and Slusarenko, A. J. 1996. Production of salicylic acid precursors is a major function of phenylalanine ammonia-lyase in the resistance of Arabidopsis to Peronospora parasitica. Plant Cell 8:203-212.

Mierziak, J., Kostyn, K., and Kulma, A. 2014. Flavonoids as important molecules of plant interactions with the environment. Molecules 19:16240-16265.

Niu, D., Wang, X., Wang, Y., Song, X., Wang, J., and Guo, J. 2016. Bacillus cereus AR156 activates PAMP-triggered immunity and induces a systemic acquired resistance through a NPR1-and SA-dependent signaling pathway. Biochem. Biophys. Res. Commun. 469:120-125.

Niu, D.-D., Liu, H.-X., Jiang, C.-H., Wang, Y.-P., Wang, Q.-Y., and Jin, H.-L. 2011. The plant growth-promoting rhizobacterium Bacillus cereus ar156 induces systemic resistance in Arabidopsis thaliana by simultaneously activating salicylate- and jasmonate/ethylene-dependent signaling pathways. Mol. Plant-Microbe Interact. 24:533-542.

Pallas, J. A., Paiva, N. L., Lamb, C., and Dixon, R. A. 1996. Tobacco plants epigenetically suppressed in phenylalanine ammonia-lyase expression do not develop systemic acquired resistance in response to infection by tobacco mosaic virus. Plant J. 10:281-293.

Pan, X., Welti, R., and Wang, X. 2010. Quantitative analysis of major plant hormones in crude plant extracts by high-performance liquid chromatographymass spectrometry. Nat. Protoc. 5:986-992.

Park, S.-W., Kaimoyo, E., Kumar, D., Mosher, S., and Klessig, D. F. 2007. Methyl salicylate is a critical mobile signal for plant systemic acquired resistance. Science 318:113-116.

Pastor, V., Balmer, A., Gamir, J., Flors, V., and Mauch-Mani, B. 2014. Preparing to fight back: Generation and storage of priming compounds. Front. Plant Sci. 5.

Petti, C., Khan, M., and Doohan, F. 2010. Lipid transfer proteins and protease inhibitors as key factors in the priming of barley responses to Fusarium head blight disease by a biocontrol strain of Pseudomonas fluorescens. Funct. Integr. Genomics 10:619-627.

Pieterse, C. M., van Wees, S. C., van Pelt, J. A., Knoester, M., Laan, R., and Gerrits, H. 1998. A novel signaling pathway controlling induced systemic resistance in Arabidopsis. Plant Cell 10:1571-1580.

Planchamp, C., Glauser, G., and Mauch-Mani, B. 2015. Root inoculation with Pseudomonas putida KT2440 induces transcriptional and metabolic changes and systemic resistance in maize plants. Front. Plant Sci. 5:719.

Qin, Y., Lu, M., and Gong, X. 2008. Dihydrorhodamine 123 is superior to 2,7dichlorodihydrofluorescein diacetate and dihydrorhodamine $6 \mathrm{G}$ in detecting intracellular hydrogen peroxide in tumor cells. Cell Biol. Int. 32:224-228.

Raguchander, T., Samiyappan, R., and Sundaramoorthy, S. 2012. Combinatorial effect of endophytic and plant growth promoting rhizobacteria against wilt disease of Capsicum annum L. caused by Fusarium solani. Biol. Control 60(1).

Richard, D., Tribot, N., Boyer, C., Terville, M., Boyer, K., and Javegny, S. 2016. First report of copper-resistant Xanthomonas citri pv. citri pathotype A causing Asiatic citrus canker in Réunion, France. Plant Dis. 101:503.

Riera, N., Handique, U., Zhang, Y., Dewdney, M. M., and Wang, N. 2017. Characterization of antimicrobial-producing beneficial bacteria isolated from Huanglongbing escape citrus trees. Front. Microbiol. 8:2415.

Ryan, R. P., Vorhölter, F.-J., Potnis, N., Jones, J. B., Van Sluys, M.-A., and Bogdanove, A. J. 2011. Pathogenomics of Xanthomonas: Understanding bacterium-plant interactions. Nat. Rev. Microbiol. 9:344-355.
Rybak, M., Minsavage, G. V., Stall, R. E., and Jones, J. B. 2009. Identification of Xanthomonas citri ssp. citri host specificity genes in a heterologous expression host. Mol. Plant Pathol. 10:249-262.

Sheikh, A. H., Raghuram, B., Eschen-Lippold, L., Scheel, D., Lee, J., and Sinha, A. K. 2014. Agroinfiltration by cytokinin-producing Agrobacterium sp. strain GV3101 primes defense responses in Nicotiana tabacum. Mol. Plant-Microbe Interact. 27:1175-1185.

Shine, M. B., Yang, J.-W., El-Habbak, M., Nagyabhyru, P., Fu, D.-Q., and Navarre, D. 2016. Cooperative functioning between phenylalanine ammonia lyase and isochorismate synthase activities contributes to salicylic acid biosynthesis in soybean. New Phytol. 212:627-636.

Stall, R. E., Miller, J. W., Marco, G. M., and de Echenique, B. I. C. 1980. Population dynamics of Xanthomonas citri causing cancrosis of citrus in Argentina. Proc. Annu. Meet. Fla. State Hortic. Soc. http://agris.fao.org/ agris-search/search.do?recordID=US8133082

Tiwari, S., Meyer, W. L., and Stelinski, L. L. 2013. Induced resistance against the Asian citrus psyllid, Diaphorina citri, by $\beta$-aminobutyric acid in citrus. Bull. Entomol. Res. 103:592-600.

Ton, J., Flors, V., and Mauch-Mani, B. 2009. The multifaceted role of ABA in disease resistance. Trends Plant Sci. 14:310-317.

Trivedi, P., Spann, T., and Wang, N. 2011. Isolation and characterization of beneficial bacteria associated with citrus roots in Florida. Microbial. Ecol. 62:324-336.

van de Mortel, J. E., de Vos, R. C. H., Dekkers, E., Pineda, A., Guillod, L., and Bouwmeester, K. 2012. Metabolic and transcriptomic changes induced in Arabidopsis by the rhizobacterium Pseudomonas fluorescens SS101. Plant Physiol. 160:2173-2188.

van Loon, L. C., Bakker, P. A. H. M., and Pieterse, C. M. J. 1998. Systemic resistance induced by rhizosphere bacteria. Annu. Rev. Phytopathol. 36: 453-483.

Walters, D. R., and Bennett, A. E. 2014. Microbial Induction of Resistance to Pathogens. Pages 149-170 in: Induced Resistance for Plant Defense. D. R. Walters, A. C. Newton, and G. D. Lyon, eds. John Wiley \& Sons, Ltd.

Wang, C., El-Shetehy, M., Shine, M. B., Yu, K., Navarre, D., and Wendehenne, D. 2014. Free radicals mediate systemic acquired resistance. Cell Reports 7: 348-355.

Wendehenne, D., Gao, Q., Kachroo, A., and Kachroo, P. 2014. Free radicalmediated systemic immunity in plants. Curr. Opin. Plant Biol. 20:127-134.

Wildermuth, M. C., Dewdney, J., Wu, G., and Ausubel, F. M. 2001. Isochorismate synthase is required to synthesize salicylic acid for plant defence. Nature 414:562-565.

Zamioudis, C., and Pieterse, C. M. J. 2012. Modulation of host immunity by beneficial microbes. Mol. Plant-Microbe Interact. 25:139-150.

Zhang, M., He, Z., Calvert, D. V., Stoffella, P. J., and Yang, X. 2003a. Surface runoff losses of copper and zinc in sandy soils. J. Environ. Qual. 32:909-915.

Zhang, M. K., He, Z. L., Calvert, D. V., Stoffella, P. J., Yang, X. E., and Lamb, E. M. 2003b. Accumulation and partitioning of phosphorus and heavy metals in a sandy soil under long-term vegetable crop production. J. Environ. Sci. Health A Tox. Hazard Subst. Environ. Eng. 38:1981-1995.

Zhang, Y., Xu, J., Riera, N., Jin, T., Li, J., and Wang, N. 2017. Huanglongbing impairs the rhizosphere-to-rhizoplane enrichment process of the citrus rootassociated microbiome. Microbiome 5:97.

Zhou, X. X., He, Z. L., Liang, Z. B., Stoffella, P. J., Fan, J. H., Yang, Y. G., and Powell, C. A. 2011. Long-term use of copper-containing fungicide affects microbial properties of citrus grove soils. Soil Sci. Soc. Am. J. 75:898-906. 